\title{
Tempeh Gembus Cookies as an Alternative Snack for Obese Adolescent Girls
}

\author{
Elserinawati Sinambela, Diana Nur Afifah*, Hartanti Sandi Wijayanti, Fillah Fithra Dieny
}

ABSTRACT

Background: Tempeh gembus is a food that high in protein and fiber but low in fat. The low content of fat in tempeh gembus is good for obese adolescents. Tempeh gembus cookies could be the alternative snack for obese adolescent girls

Objectives: To analyze the effect of the substitution of tempeh gembus flour on the nutrient content of tempeh gembus cookies and the acceptability of the best formula in the tempeh gembus cookies.

Methods: This was an experimental research with one factor complete randomized design, which was the formulation of cookies with tempeh gembus flour of $0 \%, 25 \%, 50 \%$, and $100 \%$ as the variation of substitution, then analyzed the nutrients and acceptance. The statistic method used were One-way Anova test to analyze the nutrients and Friedman test to analyze the acceptance.

Results: There were significant effects on the formulation of cookies with tempeh gembus flour on total fat, carbohydrate, total crude fiber, ash content, and reduced sugar. In acceptance test, there were significant effects of tempeh gembus cookies formulation on color, appearance, tenderness, aroma, and flavor.

Conclusions: Cookies with tempeh gembus flour formulation of $100 \%$ was the best formulation to meet total energy, carbohydrate, low fat and high fiber acceptance which were good for obese adolescent girls. Whereas cookies with tempeh gembus flour formulation of $25 \%$ and $50 \%$ based on acceptance were still acceptable and preferred.

Keywords: nutrition facts, acceptance test, tempeh gembus, cookies

\author{
*Correspondence: \\ d.nurafifah.dna@fk.undip.ac.id \\ Diana Nur Afifah \\ Department of Nutrition Science, Faculty of Medicine, Universitas Diponegoro, Semarang, Indonesia
}

\section{INTRODUCTION}

The achievement of the Human Development Index (HDI) is in line with health quality improvement. In fact, there are still so many nutritional problems that can affect health quality such as overweight or obesity. The prevalence of obesity increased more with age ${ }^{1}$. Data from the National Health and Nutrition Examination Survey (NHANES) states the obesity prevalence among adolescents aged $12-19$ years old in $1999-2000$ was $10.4 \%$ and was increased to $16.9 \%$ in $2007-2008^{2}$. Data Riskesdas 2007 of obesity prevalence was $1.4 \%$ and experienced a significant increase to $19.1 \%$ in 2013 for children over 15 years.

Adolescent obesity is the accumulation of body fat that gradually increase, which tends to increase more among girls $(20.9 \%)$ than boys $(4.2 \%)^{3}$. Obesity occurs because of a very complex interaction between parental fatness, dietary habit, and lifestyle ${ }^{4}$. Obesity is a serious problem for adolescents, especially girls since the stigma of perfect look with lean body shape ${ }^{1}$. Other factors of obesity in adolescents are excess food intake from allround processed foods, soft drinks, fast food (burgers, pizza, hot dog), and other ready-to-eat food which contain fat, high sugar, and low fiber ${ }^{5}$.

Tempeh gembus is a byproduct of leftover soy milk and tofu processing ${ }^{6}$. The National Research Council states that gembus (Okara) can be consumed by diets and obese people ${ }^{7}$. Tempeh gembus is well-known as healthy food since it has high fiber and low fat which is suitable for obesity ${ }^{6}$. The low-fat content in tempeh gembus can be used as an alternative and substitute for a snack for obese adolescents who consume high-calorie foods ${ }^{2}$.

Based on My Pyramid Equivalents Database for USDA Food Codes NHANES 2005-2006, cookies are the most favorable food group for young women after junk food at a percentage of $38 \%{ }^{7}$. Cookies are the type of snack that meet human energy needs ${ }^{7}$. In Indonesia and various countries, cookies are defined as a snack with various flavors, long shelf life, and low cost. The main things that affect the quality of cookies are texture, taste, and appearance. Another important aspect is the design of cookies with good nutritional value. Consumer acceptability remains a major factor in determining the success of the products developed ${ }^{8}$. Therefore, the use of gembus as one of the basic ingredients in making cookies 
can be used as one of the functional foods and nutritious products that are high in fiber, vitamins, minerals, and carbohydrates, fats, low ${ }^{7}$. In addition, it can also be used as an alternative snack for obese people, especially obese adolescent girls. Therefore, this study aims to analyze how the nutritional and organoleptic content of the tempeh gembus cookies.

\section{METHOD}

This research is divided into two stages. First, tempeh gembus is processed into a form of flour. The second is making tempe gembus cookies with substitution of tempeh gembus flour. The tests carried out were the proximate test (total protein content, total fat content, total crude fiber, total moisture content, total calories). and the acceptance test for tempeh gembus cookies using the hedonic test (color, aroma, texture, and taste) with 4 rating scales, namely 1 (very dislike), 2 (dislike), 3 (like), 4 (very like) by 25 panelists trained in the Universitas Diponegoro, Semarang. The criteria for panelists in this study were adolescents aged $16-20$ years, $\mathrm{BMI}>25 \mathrm{~kg} / \mathrm{m}^{2}$ and waist circumference $>80 \mathrm{~cm}$ for women. The results of hedonic measurements were categorized into 4 scales, namely very dislike (1.00 - 1.45); dislike (1.5-2.45); likes (2.5-3.45); and very like (3.50-4.00) 9. The formulation of the ingredients in the manufacture of tempeh gembus cookies as the basic material for determining the experimental formulation in this study is shown in Table 1.

Table 1. Experimental Formulation

\begin{tabular}{lccccc}
\hline Materials & $\mathbf{0 \%}$ & $\mathbf{2 5 \%}$ & $\mathbf{5 0 \%}$ & $\mathbf{7 5 \%}$ & $\mathbf{1 0 0 \%}$ \\
\hline Wheat flour (g) & 250 & 187,5 & 125 & 62,5 & 0 \\
Tempeh gembus flour (g) & 0 & 62,5 & 125 & 187,5 & 250 \\
Skimmed milk (g) & 20 & 20 & 20 & 20 & 20 \\
Refined sugar (g) & 125 & 125 & 125 & 125 & 125 \\
Butter (g) & 100 & 100 & 100 & 100 & 100 \\
Salt (g) & 1 & 1 & 1 & 1 & 1 \\
Eggs (g) & 180 & 180 & 180 & 180 & 180 \\
\hline
\end{tabular}

The process of making cookies began by mixing the dough until the dough becomes smooth. The weight of 1 wet cookie was 10 grams and dry weight after being oven for 20 minutes at a temperature of $150{ }^{\circ} \mathrm{C}$ to 8 grams. Furthermore, the cooked cookies are allowed to cool before being packed.

Determination of protein content using the Bradford method and then tested by spectrophotometry $(\lambda=595 \mathrm{~nm})$, fat using the Soxhlet method and total calories tested using manual calculations ${ }^{10}$. Testing the ash content using the oven method using a furnace at 550 ${ }^{\circ} \mathrm{C}$ for 6 hours and levels water using a dexilator oven with a temperature of $115{ }^{\circ} \mathrm{C}$ for 8 hours, then weighed again ${ }^{11}$. Total carbohydrates are calculated using the by difference method as the residual content of water, ash, fat, and protein. The total crude fiber used the AOAC 1995 method. Determination of total reducing and nonreducing sugars using the Luff Schrooll method ${ }^{12}$. Acceptance tests through a questionnaire form to determine the level of acceptance of cookies products.

All data that has been collected is processed using statistical software. Before being processed, the data was tested for normality using a manual Microsoft Excel application, then the data was tested by using the Oneway test. The acceptance level test used the Friedman test with a $95 \%$ confidence degree, followed by the Tuckey posthoc test to determine the real difference between treatments.

\section{RESULTS AND DISCUSSIONS}

The Nutrition Content of Cookies with the Substitution of Tempeh Gembus Flour

The energy content of the cookies in the four formulas ranges from 403.1-510.3 kcal / 100 grams. The energy and nutrient content contained in tempeh gembus in 100 grams are shown in Table 2. The results of statistical tests in Table 3 show that there is an effect of substitution of tempeh gembus flour on tempeh gembus cookies on the total calorie content $(p<0.001)$. The highest total calories were found in the control formula while the lowest total calories were found in the $100 \%$ tempeh gembus formulation cookies. Energy needs for adolescents aged 16-19 based on the RDA of 2000-2200 $\mathrm{kcal} / \mathrm{day}^{13}$. Cookies with substitution of tempeh gembus flour can be used as a way to fulfill the energy needs of adolescents. Tempeh gembus cookies provide energy contribution of $9.9 \%$ in 4 cookies. The addition of wheat flour increases water absorption, where in research on protein content in soybean substitution, the addition of $15 \%$ gembus flour causes the energy content to decrease, the fortification of wheat flour with increased gembus flour causes a decrease in the total energy content ${ }^{11}$.

The highest protein content was found in control cookies and the lowest was in cookies of $50 \%$ tempeh gembus formulation. The result of the protein content in cookies is unstable because the cookies are made from fermented flour. The longer the fermentation takes, the protein content of the cookies decreases more because it is influenced by the protein content of fermented flour before it is processed into cookies ${ }^{12}$. As well as fermentation, the protein content in cookies becomes unstable due to the use of a blender that is not constant during the refining process of tempeh gembus. Previous research states that the milling process with a blender can reduce the protein quality. 14 . The protein content contained in the tempeh gembus cookies with a $100 \%$ formulation is 2.79 grams $/ 100$ grams. The protein requirement for young women is $0.8 \mathrm{~g} / \mathrm{kgBW}$, the protein content in cookies has met the protein needs of young women. 
Table 2. Energy Content and Nutrients of Tempe Gembus Flour (100 grams)

\begin{tabular}{lc}
\hline Nutrients & \\
\hline Energy (Kcal) & $271.69 \pm 7.97$ \\
Protein $(\mathrm{g})$ & $2.81 \pm 0.48$ \\
Fat $(\mathrm{g})$ & $0.25 \pm 0.03$ \\
Carbohydrates $(\mathrm{g})$ & $75.12 \pm 1.49$ \\
Crude Fiber $(\mathrm{g})$ & $41.16 \pm 4.94$ \\
Water $(\mathrm{g})$ & $2.20 \pm 0.14$ \\
Ash $(\mathrm{g})$ & $2.00 \pm 0.14$ \\
Reduced Sugar (g) & $0.06 \pm 0.00$ \\
Non-Reduced Sugar $(\mathrm{g})$ & $0.03 \pm 0.00$ \\
\hline
\end{tabular}

The comparison of the protein content of wheat flour and tempeh gembus flour did not have a different effect, the protein content contained in cookies with the formula of tempeh gembus flour had decreased, the more the formula of tempeh gembus flour was that the protein content decreased compared to control cookies. The protein content contained in 100 grams of medium protein flour is around 8 grams $/ 100$ grams, when compared to tempeh gembus flour is only 2.81 grams $/ 100$ grams. The increasing substitution of gembus flour makes the protein content decrease, this is in accordance with several studies on substitution of gembus flour at several levels of cookie treatment ${ }^{7}$.

Table 3. Results of Average Energy and Nutrient Content of Cookies with Wheat Flour Substitution (100 grams)

\begin{tabular}{ccccccc}
\hline \multirow{2}{*}{ Formulas } & \multicolumn{5}{c}{ Average Nutrient Content } \\
\cline { 2 - 7 } & Energy** (Kcal) & Protein (\%) & Fat (\%) & Carbohydrate***(\%) & Water (\%) & Ash (\%) \\
\hline Control & $501.3 \pm 2.39^{\mathrm{a}}$ & $3.04 \pm 1.02$ & $33.70 \pm 0.42^{\mathrm{a}}$ & $48.74 \pm 0.09^{\mathrm{d}}$ & $14.00 \pm 1.41$ & $1.70 \pm 0.14^{\mathrm{c}}$ \\
$25 \%$ & $450.4 \pm 6.41^{\mathrm{b}}$ & $2.35 \pm 0.03$ & $21.50 \pm 1.83^{\mathrm{b}}$ & $63.63 \pm 2.52^{\mathrm{c}}$ & $12.5 \pm 0.70$ & $2.55 \pm 0.07^{\mathrm{b}}$ \\
$50 \%$ & $441.2 \pm 1.11^{\mathrm{b}}$ & $1.56 \pm 0.84$ & $20.40 \pm 0.84^{\mathrm{b}}$ & $64.01 \pm 1.42^{\mathrm{bc}}$ & $12.00 \pm 2.82$ & $2.55 \pm 0.07^{\mathrm{b}}$ \\
$75 \%$ & $445.5 \pm 1.39^{\mathrm{b}}$ & $1.68 \pm 1.23$ & $18.50 \pm 0.14^{\mathrm{b}}$ & $69.33 \pm 0.33^{\mathrm{b}}$ & $10.50 \pm 2.12$ & $2.60 \pm 0.28^{\mathrm{b}}$ \\
$100 \%$ & $397.5 \pm 5.47^{\mathrm{c}}$ & $1.88 \pm 0.74$ & $7.70 \pm 0.98^{\mathrm{c}}$ & $81.59 \pm 1.04^{\mathrm{a}}$ & $7.00 \pm 2.85$ & $3.30 \pm 0.14^{\mathrm{a}}$ \\
\hline$p$ value & $<0.001^{*}$ & $0.506^{*}$ & $<0.001^{*}$ & $<0.001^{*}$ & $0.075^{*}$ & $0.002^{*}$ \\
\hline
\end{tabular}

Note: Numbers followed by different superscript letters ( $a, b, c, d)$ show significant differences.

* Testing with One-way because the data is normally distributed

** Total energy: Energy from Protein + Fat + Carbohydrates

*** Calculation of total carbohydrates uses the formula by difference (AOAC 1995), by adding up protein + fat + water + ash.

In Table 3, there is an effect of substitution of tempeh gembus flour on total fat $(p<0.001)$ where the group is $100 \%$ different from $25 \%, 50 \%, 75 \%$ and control, the lowest total fat is found in cookies with $100 \%$ tempeh gembus flour formula while the highest total fat was found in controls. The fat content in dry gembus flour is 0.25 grams / 100 grams, while the fat content in cookies is 33.70 grams / 100 grams. The amount of fat content in tempeh gembus depends on the soybean variety used, the content of tempeh gembus flour can have large or small amounts of fat, resulting in excess amount of oil. The substitution of tempeh gembus flour in each treatment caused a decrease in the total fat content in the soft tempe cookies. This is due to the presence of unsaturated fatty acids in tempeh gembus such as linoleic acid $^{15}$.

For total carbohydrates, there is also an effect of substitution of tempeh gembus flour $(p<0.001)$. Based on Table 3, control cookies have a lower carbohydrate content compared to $100 \%$ tempeh gembus flour. The carbohydrate content in the tempeh gembus cookies ranged from 48.74-81.59 grams/100 grams. This contributed around 14.33-34.83 grams of crude fiber in 100 grams, 2.25-5.7 grams of sugar in 100 grams. The carbohydrate content in cookies has increased along with the addition of tempeh gembus ${ }^{16}$. The increase in total carbohydrates in cookies with the formula of tempeh gembus can be influenced by the drying process of wet tempeh gembus into dry tempeh. When tempeh gembus is dried properly, the proportion of all elements of tempeh gembus that is dried increases. Dry tempeh gembus has a higher carbohydrate value than wet tempeh. In the drying process, using an oven with a hot temperature of almost $98 \%$ moisture is removed due to the physicochemical properties. The increase in carbohydrate content increased because the ingredients used in the manufacture of cookies, namely wheat flour contributed 74.48 grams/100 grams, eggs 0.9 grams per serving and margarine used in making cookies contributed $0 \%$ carbohydrates.

There is an effect of substitution of tempeh gembus flour on the total crude fiber $(p=0.018)$, the higher the tempeh gembus flour used, the higher the total crude fiber. This is shown by the results in Table 4 where the total crude fiber is $100 \%$ higher than the control. Tempeh gembus was chosen as a substitute for flour because it contains important nutrients such as essential fatty acids, protein, carbohydrates, fiber, calcium, and iron ${ }^{17}$. In addition, tempeh gembus contains a large amount of crude fiber consisting of cellulose, hemicellulose, and lignin, and polysaccharides. Consumption of dietary fiber from tempeh gembus is known to have the effect of decreasing the fat profile ${ }^{18}$. In addition, tempeh gembus has been studied to have proteolytic, fibrinolytic and anti-inflammatory properties that may act as antithrombotic in blood capillaries ${ }^{19-21}$. Other research states that tempeh gembus also has antioxidant and antimicrobial activity ${ }^{22,23}$. The need for fiber in adolescent ranges from 21-40 grams/day. The fiber found in cookies with the formula of tempeh gembus ranges from 14.33-34.83 grams / 100 grams. Increasing the amount of crude fiber is in the cookies with the formulation of tempeh gembus. Because tempeh gembus is a product of fermentation, during the fermentation process there is a high hydrostatic pressure reaction. Another study states that during the fermentation process of tempeh gembus, there is also an increase in protein content up to $6.7 \%{ }^{25}$. Chemical or enzymatic 
treatment, fermentation, extrusion, high pressure, and micronization can increase the fiber content in tempeh gembus, which improves the quality of its nutritional content and processing properties ${ }^{26}$. The crude fiber content of the cookies will increase with the addition of tempeh gembus flour, while wheat flour has crude fiber content of $0.40-0.50 \%{ }^{27}$.

Table 4. Distribution of total carbohydrate value (Crude Fiber, Reduced Sugar, Non-Reduced Sugar) (100 grams)

\begin{tabular}{cccc}
\hline Formulas & crude fiber $(\%)$ & reduced sugar $(\%)$ & Non-reduced sugar $(\%)$ \\
\hline Control & $14.33 \pm 2.82^{\mathrm{b}}$ & $3.15 \pm 0.63^{\mathrm{a}}$ & $2.55 \pm 0.21$ \\
$25 \%$ & $15.83 \pm 4.94^{\mathrm{b}}$ & $2.85 \pm 0.21^{\mathrm{a}}$ & $3.15 \pm 0.63$ \\
$50 \%$ & $18.99 \pm 8.95^{\mathrm{ab}}$ & $2.25 \pm 0.63^{\mathrm{ab}}$ & $3.00 \pm 0.84$ \\
$75 \%$ & $34.00 \pm 1.41^{\mathrm{a}}$ & $1.50 \pm 0.42^{\mathrm{ab}}$ & $1.50 \pm 0.42$ \\
$100 \%$ & $34.83 \pm 0.70^{\mathrm{a}}$ & $0.75 \pm 0.21^{\mathrm{b}}$ & $1.50 \pm 0.42$ \\
\hline$p$ value & $0.018^{*}$ & $0.017^{*}$ & $0.075^{*}$
\end{tabular}

Note: Numbers followed by different superscripts $(a, b, c, d)$ indicate significant differences

* Testing with One-way ANOVA because the data is normally distributed

There is no effect of substitution of tempeh gembus flour on moisture content $(p=0.005)$. Water is an important component in food ingredients. All food ingredients contain different amounts of water, from both animal or vegetable food supplies. Determination of water content is the most important and most extensive analysis performed in food processing and testing. Water content has a direct effect on the stability and quality of food $^{16}$. The greater the heat given and the longer the heating, the less water content of food is in large quantities.

Based on the results of the analysis on 5 samples, the addition of tempeh gembus flour also had an effect on the ash content $(p=0.002)$. The ash content increased in the formulation of cookies with $100 \%$ tempeh gembus flour, the ash content of the control was lower than the ash content of $100 \%$ cookies. Ash is an organic substance left over from the combustion of an organic material. The ash content contained in a food material depends on the type of material and the method of ashes. Ash content has to do with the minerals of a material ${ }^{15}$.

There is an effect of substitution of tempeh gembus on reducing sugars ( $p=0.017)$, reducing sugars in using tempeh gembus flour is $100 \%$ lower than control cookies. There is no effect of substitution of tempeh gembus flour on the total content of non-reducing sugar $(p=0.075)$. Meanwhile, the highest non-reducing sugar content was found in control cookies and the lowest was at $100 \%$. The heating process when drying tempeh gembus flour affects the reducing sugar content. The drying time will increase the reducing sugar content. Based on the results of the research, the reducing sugar content of tempeh gembus flour decreased at each substitution. This is due to a decrease in water content so that the percentage of reducing sugar increases ${ }^{28}$.

The non-reducing sugar content in the four formulations ranged from 2.55-1.50 gr / 100 grams. Based on the results of the study, there was a decrease in the total sucrose in cookies which received formulation treatment from tempeh gembus flour. Sucrose is easily inverted into glucose and fructose under acidic conditions and high temperatures, namely $60^{\circ} \mathrm{C}$. The presence of $\mathrm{OH}$ ions in the sucrose solution will cause sucrose to decompose and form 5-hydroxy-methyl-2-furfural, methyl glyoxyl, glyceraldehyde, dioxyacetone, acetone, phenolic compounds and $\mathrm{CO} 2$. These compounds will give the product a very dark brown color. The level of sucrose is also determined based on how much reducing sugar contained in sugar. If the sucrose level is high, the reducing sugar level will be even lower ${ }^{28}$.

Table 5. Analysis Result of Cookies Acceptance with Tempeh Gembus Formulas in Appearance, Crust, and Hardness Categories

\begin{tabular}{|c|c|c|c|c|c|c|}
\hline \multirow{2}{*}{ Formulas } & \multicolumn{2}{|c|}{ Appearance } & \multicolumn{2}{|c|}{ Crust } & \multicolumn{2}{|c|}{ Hardness } \\
\hline & Average & Preference & Average & Preference & Average & Preference \\
\hline Control & $3.24 \pm 0.779^{a}$ & Like & $3.36 \pm 0.638^{a}$ & Like & $3.32 \pm 0.748^{a}$ & Like \\
\hline $25 \%$ & $2.76 \pm 0.779^{b}$ & Like & $2.68 \pm 0.748^{c}$ & Like & $2.92 \pm 0.702^{\mathrm{b}}$ & Like \\
\hline $50 \%$ & $2.64 \pm 0.638^{c}$ & Like & $3.04 \pm 0.676^{b}$ & Like & $2.56 \pm 0.821^{c}$ & Like \\
\hline $75 \%$ & $2.24 \pm 0.779 \mathrm{e}$ & Did not like & $2.48 \pm 0.714^{\mathrm{e}}$ & Like & $2.36 \pm 0.757^{d}$ & Did not like \\
\hline $100 \%$ & $2.60 \pm 0.957^{d}$ & Like & $2.64 \pm 0.700^{d}$ & Like & $2.16 \pm 0.943^{e}$ & Did not like \\
\hline$p$ value & $<0.001^{*}$ & & $<0.001^{*}$ & & $<0.001^{*}$ & \\
\hline
\end{tabular}

Note: Numbers followed by different superscript letters ( $a, b, c, d, e)$ indicate significant differences.

* Testing with Friedman

\section{Acceptence}

The addition of tempeh gembus flour to making cookies can affect the color of the product. Based on the results in Table 5, the level of color acceptance $(p<0.001)$ has decreased, along with the addition of doses of tempeh gembus flour, the color of cookies with a formula of $75 \%$ is not preferred. The use of tempeh gembus flour results in the color of the cookies burning faster, although roasting in the oven at the same temperature and at the same time can affect the color quality of the cookies. The use of tempeh gembus which contains high protein can affect the physical quality of a product ${ }^{29}$. One of the changes in color in food products is caused by reactions between carbohydrates, especially reducing sugars and 
primary amino groups called Maillard reactions which are non-enzymatic browning reactions.

The use of tempeh gembus as an ingredient in making cookies can affect the appearance of a product, especially on cookies $(p<0.001)$. The appearance of cookies with the formula of tempeh gembus flour is considered to have a hollow surface layer. In appearance character, all cookie formulas are preferred by panelists.

Based on Table 6, it is known that the addition of tempeh gembus flour to cookies affects the aroma and taste of cookies $(p<0.001)$. The results of the panelists' assessment based on aroma, panelists did not like the aroma of cookies with the basic ingredient of tempeh gembus flour (100\%). The aroma and taste contained in cookies with tempeh flour formula is due to processing on soybeans. The unpleasant taste is produced by the lipoxidase enzyme found in soybeans. Enzymes hydrolyze fat in soybeans into hexane and hexanol group compounds. The taste of tempeh gembus cookies leaves
The main thing to pay attention to especially when mixing the dough is the spread of all the ingredients. The more evenly the ingredients of the dough are mixed, the better the quality of a product. The increased use of tempe gembus flour in making cookie dough causes the separation or cavities in cookies to decrease 8 .

a bitter aftertaste, the bitter taste comes from gembus. The protease enzymes secreted by the yeast of tempeh during the fermentation process can break down proteins into amino acids and peptides. Hydrophobic peptides that are produced from the preteolytic activity of food products that have a bitter taste, such as glycine-leucine, glycine-phenylalanine 30 . The cookie formulas of $25 \%$ and $50 \%$ tempeh gembus flour are acceptable to the panelists. Panelists like the taste of the cookies with tempeh gembus flour formula, except for the $75 \%$ and $100 \%$ tempeh gembus flour cookies formulation.

Table 6. Analysis Results of Cookies Acceptance with Tempeh Gembus Flour Formula Based on Aroma and Taste Categories

\begin{tabular}{ccccc}
\hline \multirow{2}{*}{ Formulas } & \multicolumn{3}{c}{ Aroma } & \multicolumn{2}{c}{ Taste } \\
\cline { 2 - 5 } & Average & Preference & Average & Preference \\
\cline { 2 - 5 } Control & $3.44 \pm 0.583^{\mathrm{a}}$ & Like & $3.68 \pm 0.557^{\mathrm{a}}$ & Most Liked \\
$25 \%$ & $2.72 \pm 0.458^{\mathrm{c}}$ & Like & $2.92 \pm 0.572^{\mathrm{c}}$ & Like \\
$50 \%$ & $3.04 \pm 0.735^{\mathrm{b}}$ & Like & $3.04 \pm 0.6667^{\mathrm{b}}$ & Like \\
$75 \%$ & $2.48 \pm 0.823^{\mathrm{d}}$ & Like & $2.32 \pm 0.802^{\mathrm{d}}$ & Did not like \\
$100 \%$ & $2.28 \pm 0.792^{\mathrm{e}}$ & Did not like & $2.00 \pm 0.913^{\mathrm{e}}$ & Did not like \\
\hline$p$ value & $<0.001^{*}$ & & $<0.001^{*}$ &
\end{tabular}

Based on the results in Table 5, cookies with the tempeh gembus flour formula has a significant effect on acceptance in terms of tenderness $(p<0.001)$. The hardness assessment referred the softness of the cookies when chewed by the panelist. The higher the formula of tempeh gembus flour in cookies, the level of acceptance and liking of cookies decreases. The addition of tempeh gembus flour to cookies reduces the level of acceptance of hardness. The high fiber content affects the hardness of the cookies. The compaction of fiber and protein makes cookies less brittle. The combination of tempeh gembus flour makes the cookies tougher ${ }^{7}$. The end result of adding the tempeh gembus flour is not so homogeneous with the cookies. The final texture of the cookies becomes less cohesive due to the difference between the particle size of the flour and the tempeh gembus flour ${ }^{31}$.

\section{The Best Product Choice}

The best products chosen are cookies with a $100 \%$ formula. Based on the results of total calories, fat, and fiber, formula cookies products are $100 \%$ superior to other formula products. However, for protein content, all product formulas do not meet the Indonesian National Standard requirements. The best product in terms of product acceptance with a cookie formula of $25 \%$ and $50 \%$ overall is still acceptable in terms of color, appearance, taste, aroma, and hardness.

\section{CONCLUSIONS}

The nutritional content of $100 \%$ tempeh gembus cookies was the best formulation to meet the energy needs, carbohydrates, low fat and high fiber starch which is good for obese adolescent girls. In comparison, the acceptance of tempeh gembus cookies formula is $25 \%$ and $50 \%$, which are still acceptable and sufficient preferred. Tempeh gembus cookies can be used as an alternative snack for obese adolescent girls who are low in fat and high in fiber. Further research is needed to develop a formulation of tempeh gembus cookies that meet the Indonesian National Standard quality requirements.

\section{ACKNOWLEDGMENT}

The authors would like to thank all parties involved in this research.

\section{REFERENCES}

1. Diana, R., Yuliana, I., Yasmin, G. \& Hardinsyah. Faktor risiko kegemukan pada wanita dewasa indonesia. J. Gizi dan Pangan 8, 1-8 (2013).

2. Ogden, C. \& Carroll, M. Prevalence of Obesity Among Children and Adolescents : United States, Trends 1963 - 1965 Through 2007 - 2008. Natl. Cent. Heal. Stat. (2010).

3. Ali, A.T. \& Crowther, N.J. Factors predisposing to obesity : a review of the literature. J. Endocrinol. Metab. Diabetes South Africa 14, 81-84 (2009).

4. Suryaputra, K. \& Nadhiroh, S.R. Perbedaan Pola Makan dan Aktivitas Fisik antara Remaja Obesitas dan Non Obesitas. Makara Kesehat. 16, 45-50 (2012).

5. Sartika, R.A.D. Faktor Risiko Obesitas pada Anak 
5-15 tahun di Indonesia. Makara Kesehat. 15, 37-43 (2011).

6. Lu, F., Cui, Z., Liu, Y. \& Li, B. The Effect of Okara on the Qualities of Noodle and Steamed Bread. Adv. J. Food Sci. Technol. 5, 960-968 (2013).

7. Gemede, H.F., Ratta, N., Haki, G.D., Woldegiorgis, A.Z. \& Beyene, F. Nutritional Quality and Health Benefits of Okra (Abelmoschus esculentus): A Review. J. Food Process. Technol. 6, 1-6 (2015).

8. Sebastian, R.S., Goldman, J.D. \& Enns, C.W. Snack Patterns of U.S Adolescents: What We Eat in America, NHANES 2005 - 2006. Food Surveys Research Group Dietary Data Brief 56, (2011).

9. Park, J., Choi, I. \& Kim, Y. Cookies formulated from fresh okara using starch, soy flour and hydroxypropyl methylcellulose have high quality and nutritional value. LWT - Food Sci. Technol. 63, 660-666 (2015).

10. Ostermann-porcel, M.V, Quiroga-panelo, N., Rinaldoni, A.N. \& Campderrós, M. E. Incorporation of Okara into gluten-free cookies with high quality and nutritional value. Hindawi J. Food Qual. 2017, 1-8 (2017).

11. Pankuku \& Singh. Utilization of Soy Okara in preparation of Nutraceutical Buns for Food Security. in The 8th AFMA Congress Moi University Press 283-292 (2012).

12. Ayustaningwarno, F. Teknologi Pangan, Teori Praktis dan Aplikasi. (Penerbit Graha Ilmu, 2014).

13. Angka Kecukupan Gizi (AKG). PMK No. 75 tentang Angka Kecukupan Gizi Bangsa Indonesia 1-10 (2013). Available at: https://peraturan.bkpm.go.id/jdih/userfiles/bat ang/PMK No. 75 ttg Angka Kecukupan Gizi Bangsa Indonesia.pdf. (Accessed: 3rd July 2018)

14. Syahputri, D.A. \& Wardani, A.K. Pengaruh fermentasi Jali (Coix lacryma jobi-L) pada proses pembuatan tepung terhadap karakteristik fisik dan kimia cookies dan roti tawar. J. Pangan dan Agroindustri 3, 984-995 (2015).

15. Augustin, M.A. et al. Role of food processing in food and nutrition security. Trends Food Sci. Technol. 56, 115-125 (2016).

16. Chen, X. et al. Study on the effects of different drying methods on physicochemical properties, structure, an in vitro digestibility of Fritillaria thunbergii Mig (Zhebeimu) flours. Food Bioprod. Process. 98, 266-274 (2016).

17. Kurniasari, R., Sulchan, M., Afifah, D.N., Anjani, G. \& Rustanti, N. Influence variation of tempeh gembus (an Indonesian fermented food) on homocysteine and malondialdehyde of rats fed an atherogenic diet. Rom. J. Diabetes, Nutr. Metab. Dis. 24, 203-211 (2017).

18. Afifah, D.N., Nabilah, N., Supraba, G.T., Pratiwi, S. N. \& Sulchan, M. The Effects of Tempe Gembus, an Indonesian Fermented Food, on Lipid Profiles in Women with Hyperlipidemia. 19 (2018).

19. Afifah, D.N. et al. Purification and characterization of a fibrinolytic enzyme from Bacillus pumilus 2.g isolated from gembus, an Indonesian fermented food. Prev. Nutr. Food Sci. 19, 213-219 (2014).

20. Afifah, D.N., Sulchan, M., Syah, D., Yanti \& Suhartono, M.T. The Use of Red Oncom Powder as Potential Production Media for Fibrinogenolytic Protease Derived from Bacillus Licheniformis RO3. Procedia Food Sci. 3, 453-464 (2015).

21. Dewi, P. K., Afifah, D. N., Rustanti, N., Sulchan, M. \& Anjani, G. The effect of tempeh gembus variations to serum levels of high sensitivity creactive protein (Hscrp) and serum levels of fibrinogen of sprague dawley rats with aterogenic diet. Rom. J. Diabetes, Nutr. Metab. Dis. 25, 91-97 (2018).

22. Agustina, R.K., Dieny, F.F., Rustanti, N., Anjani, G. \& Afifah, D. N. Antioxidant activity and soluble protein content of tempeh gembus hydrolysate. Hiroshima J. Med. Sci. 67, (2018).

23. Noviana, A., Dieny, F.F., Rustanti, N., Anjani, G. \& Afifah, D.N. Antimicrobial activity of gembus hydrolyzate. IOP Conf. Ser. Earth Environ. Sci. 116, (2018).

24. Dharsenda, T., Dabhi, M., Jethva, M. \& Kapopara, M. Nutritional and Functional Characterization of Peanut Okara (Defatted Peanut) Flour Cookies. J. Grain Process. Storage 2, 24-28 (2015).

25. Damanik, R.N.S. et al. Nutritional Composition Changes during Tempeh Gembus Processing. IOP Conf. Ser. Earth Environ. Sci. 116, (2018).

26. Porcel, M.V.O., Rinaldoni, A.N., Furlan, L.T.R., Mercedes, E. \& Campderros. Influence of the Particle Sizeand Level of Substitution of Okara Flour in the Development of Gluten-Free Cookies. Int. J. Res. Advent Technol. 4, 82-92 (2016).

27. Aguado, A. Development of okara powder as a gluten free alternative to all purpose flour for value added use in baked goods. (2010).

28. Sengupta, S., Chakraborty, M., Bhowal, J. \& Bhattacharya, D.K. Study on the effects of drying process on the composition and quality of wet okara. Int. J. Sci. Environ. Technol. 1, 319-330 (2012).

29. Sundari, D., Almasyhuri \& Lamid, A. Pengaruh proses pemasakan terhadap komposisi zat gizi bahan pangan sumber protein. Media Litbangkes 25, 235-242 (2015).

30. Isyanti, M. \& Lestari, N. Perbaikan mutu gizi produk olahan pangan tradisonal opak ketan dengan penambahan tepung ampas tahu (Okara). J. Agro-based Ind. 3, 62-69 (2014).

31. Sutrisno, C.D.N. \& Susanto, W.H. Pengaruh penambahan jenis dan konsentrasi pasta (santan dan kacang) terhadap kualitas produk gula merah. J. Pangan dan Agroindustri 2, 97-105 (2014). 